Research Article

\title{
Nutritional Value of Selected Edible Ficus Fruit in Kuantan
}

\author{
Nik Nadira Nazua Nik Rusmadi ${ }^{1}$, Rozilawati Shahari ${ }^{1 *}$, Che Nurul Aini Che Amri ${ }^{1}$, \\ Nur Shuhada Tajudin ${ }^{1}$, Mohd. Radzali Mispan ${ }^{2}$ \\ ${ }^{1}$ Department of Plant Science, International Islamic University Malaysia, Kuantan, 25200, Pahang, Malaysia \\ ${ }^{2}$ Research Institute and Agricultural Development Malaysia (MARDI), Serdang, 43400, Selangor, Malaysia
}

Article history:

Submission April 2019

Revised May 2019

Accepted December 2019

*Corresponding author:

E-mail:

firdawila@iium.edu.my

\begin{abstract}
Interest in the nutritional value content in food had been increasing as one of the ways to reduce the disease among the human being. Ficus is one of the fruit that contained high in major source of nutrients. Considering the important towards the mankind, this study was conducted to evaluate the nutritional content of Ficus fruit. There were six species and varieties of Ficus used in this study. The fresh sample was collected from selected area in Kuantan, Pahang. The major proximal components such as moisture content, crude fibre, crude lipid, total ash, crude protein, carbohydrate and energy was analysed using AOAC method. Based on this study, the moisture content ranges from $36.33 \%-49.67 \%$ in F. carica cv. BTM6; crude protein $2.3 \%-4.58 \%$ in F. carica cv. TGF; crude lipid $0.01 \%$ $0.11 \%$ in F. carica cv. BTM6; total ash $14.94 \%$ - $21.22 \%$ in F. carica cv. Alma and crude fiber $0.88 \%-3.36 \%$ in F. carica cv. BTM6. The highest value of carbohydrate and energy content was found in F. hispida with $43.86 \%$ and 175.44 kJ, respectively. According to our findings, consumption of Ficus fruit is recommended for commercialized in green industry based on its nutritional content that was crucial for human health.
\end{abstract}

Keywords: Nutritional value, Wild Ficus, Cultivated Ficus, Planting medium

\section{Introduction}

In recent years, food had become a major source of human problem due to its excessive unhealthy content. In order to overcome this problem, the wild food source such as fruit had chosen to substitute the unhealthy food that contains synthetic chemicals. Fruit consumption get attention worldwide because of its taste, disease prevention and health benefits. It was due to the existence of nutrients such as carbohydrate, fibre and proteins that needs for human body $[1,2,3]$. The food with plant based are believed to be helpful in preventing many diseases. One of the ways to maintain the body weight and energy regulations is by control the estimated calories content in food [4]. Among of the edible fruit, Ficus fruit was reported to had rich and good in nutritional content [5].

Ficus are perennial woody trees categorized under mulberry family [6, 7]. It had the adventitious roots important for support system and some of this species are hemi- epiphytes and root climbers. Ficus can be classified based on its vegetative and reproductive morphology [8]. The inflorescence of Ficus had the specific term that was synocia, unique as they enclose both staminate and pistillate flower during anthesis. Commonly, the ripen Ficus becomes yellow to orange or red, or pink to red based on its species and varieties.

Ficus fruit are used as traditional medicine to treat various diseases such as gastrointestinal (coli, indigestion, loss of appetite and diarrhea), respiratory (sore throats, coughs and bronchial problem), inflammatory (cardiovascular disorder, ulcerative disease and cancer [9, 10]. In Japan, the dried leaves, aerial roots and bark of $F$. microcarpa have been widely used as folk medicine for controlling perspiration, alleviating fever and relieving pain [11]. F. carica enriched with many elements such as calcium, iron, strontium, phosphorus, magnesium, potassium, 
Vitamin C and Vitamin B [12]. It is also high in fibre and highest in overall mineral content [13].

F. carica fruits can also be prepared as jam has excellent source of minerals, vitamins, carbohydrate and dietary fibre because it is fat and cholesterol free and contain high content of amino acids $[14,15]$. F . carica was widely develop as food product. However, only F. carica are widely commercialized as a major of food product compare to other Ficus. Therefore, this study was conducted to determine the nutritional value of selected edible Ficus fruit in Kuantan. The information about the nutritional value can give the knowledge about the Ficus fruit nutrient content. It was supported by study from Sadia et al. (2014) that even the wild species are lack in taste, it has high in several nutritional value [16].

\section{Material and Methods}

The ripen fruits of Ficus were collected from selected area in Kuantan. The fruit part was oven dried to undergo further nutritional value analysis.

Moisture content were determined by weighing $5 \mathrm{~g}$ of fresh sample before and after oven dry at $65^{\circ} \mathrm{C}$ until the weight become constant. The crude protein content was analysed by using Kjedahl method and crude protein were calculated as $\mathrm{N} \times 6.25$. The ash content was done by incineration in a muffle furnace at $600^{\circ} \mathrm{C}$ for 3 hours. Crude lipid was done by extract the sample with petroleum ether in a Soxhlet apparatus. Crude fibre was extracted with $1.25 \% \mathrm{NaOH}$, drying the residue for an hour at $105^{\circ} \mathrm{C}$ followed by muffle incineration at $600^{\circ} \mathrm{C}$. Total carbohydrate was calculated by using formula [100 - (moisture + protein + fat + ash)] while gross food energy was calculated using formula [ $4 \times$ protein, $4 \times$ carbohydrate, $9 \times$ fat]. Lastly, the ANOVA analysis was done by using SAS version 9.4 and means was compared by Duncan's multiple range test.

\section{Results and Discussion}

Nutritional value of ripens fruit for selected Ficus species were recorded to reveals its potential health benefits [26]. It is important to get the idea about the preferable Ficus fruit that can give the highest nutritional values in the ripens fruit content. The analyses showed a significant difference of nutritional content among Ficus species (Table $1)$.
The results show that the $F$. carica resulted highest in crude protein, crude fibre, crude lipid, moisture content and total ash compared to others Ficus. Based on this study, the highest crude protein was observed in F. carica cv. BTM6 (4.58\%) whereas the lowest one was observed in F. carica cv. Alma (2.30\%). Proteins are important component of diet needed for survival of animals and human beings to supply adequate amounts of required amino acids for nutrition [17]. The insufficient amount of protein in human body can causes many health problems such as kwashiorkor, marasmus, impaired mental health, edema, organ failure, wastes and shrinkage of muscle tissue and weakness of human system [18].

The highest moisture content was observed in F. carica cv. BTM6 (59.67\%) whereas the lowest value was observed in Ficus hispida (36.33\%). The water stored and nutrient uptake by the wild plant was varies according to the habitat of the plant [19]. For instance, F. fistulosa that can be found widely in wet area recorded higher moisture content compare to F. hispida due to the water uptake from its own habitat. On the other hands, the moisture content in the fruit increased the weight of fruit per gram. The lesser water contents in the fruit slower the degradation process by microorganism and chemical changes [20]. For preservation of the product, it must to be dry to remove the water and decrease the moisture content [21]. Based on this study, F. carica cv. BTM6 contains more than $50 \%$ of water showed that it had highest in moisture content.

Fiber and moisture content have been observed to have correlation between each other. The water in the fruit means that its own high fiber value, which could be interest to human health as the fibrous that easily digested and disintegrated [22]. The high content of fiber in human body can helps in digestion and absorption in the human small intestines [23]. Fiber content ranged from $0.08 \%$ to $3.36 \%$ with $F$. carica cv. BTM6 recorded the highest value.

Low crude lipid content means decrease in fat of the fruit can be helpful in weight loss [26]. The higher value of crude lipid content in F. carica cv. BTM6 (0.11\%) reflect that these fruits only contain less than $0.5 \%$ of fat per meal consume. The fats need to be control and limited not more than $30 \%$. The excessive fat content in food can lead to 
Table 1. Nutritional value of selected Ficus fruit

\begin{tabular}{|c|c|c|c|c|c|c|c|}
\hline Species & $\begin{array}{c}\text { Moisture } \\
\text { content (\%) }\end{array}$ & $\begin{array}{l}\text { Crude pro- } \\
\text { tein (\%) }\end{array}$ & $\begin{array}{c}\text { Crude } \\
\text { Lipid } \\
(\%)\end{array}$ & $\begin{array}{c}\text { Crude fiber } \\
\text { (\%) }\end{array}$ & $\begin{array}{l}\text { Total ash } \\
\text { (\%) }\end{array}$ & $\begin{array}{l}\text { Carbohy- } \\
\text { drate (\%) }\end{array}$ & $\begin{array}{c}\text { Energy (kcal/ } \\
\text { kJ) }\end{array}$ \\
\hline F. auriculata & $44.33 \pm 7.4$ & $3.19 \pm 1.0$ & $0.01 \pm 0$ & $1.82 \pm 1.0$ & $15.22 \pm 3.4$ & $35.42 \pm 4.5$ & $141.68 \pm 22.7$ \\
\hline F. hispida & $36.33 \pm 5.6$ & $3.11 \pm 1.0$ & $0.00 \pm 0$ & $1.71 \pm 1.0$ & $14.94 \pm 3.1$ & $43.86 \pm 5.3$ & $175.44 \pm 28.1$ \\
\hline F. fistulosa & $44.0 \pm 5.3$ & $2.90 \pm 1.0$ & $0.02 \pm 0$ & $1.61 \pm 1.0$ & $15.91 \pm 3.6$ & $35.66 \pm 4.4$ & $142.29 \pm 23.4$ \\
\hline $\begin{array}{c}\text { F. carica cv. } \\
\text { BTM6 }\end{array}$ & $59.67 \pm 8.9$ & $2.55 \pm 0.8$ & $0.11 \pm 0$ & $3.36 \pm 1.0$ & $20.54 \pm 4.8$ & $13.78 \pm 2.8$ & $55.12 \pm 10.8$ \\
\hline $\begin{array}{c}\text { F. carica cv. } \\
\text { TGF }\end{array}$ & $47.0 \pm 7.5$ & $4.58 \pm 1.0$ & $0.03 \pm 0$ & $0.88 \pm 0.3$ & $19.34 \pm 4.2$ & $28.18 \pm 3.4$ & $112.70 \pm 20.8$ \\
\hline $\begin{array}{c}\text { F. carica cv. } \\
\text { Alma }\end{array}$ & $49.67 \pm 7.8$ & $2.30 \pm 0.7$ & $0.08 \pm 0$ & $2.58 \pm 1.2$ & $21.22 \pm 5.1$ & $23.49 \pm 3.6$ & $96.62 \pm 13.2$ \\
\hline
\end{tabular}

increase the calories in human body and also exposed human to risk health [24]. In contrast, the study conducted by Sadia et al. (2014) suggested that the F. carica crude lipid was lower in content compared to Ficus glomerata and Ficus palmate [16]. Instead of consume F. carica, other Ficus also recommended to be consumed because of its lower crude lipid content.

The ash contains inorganic material of the plant that can destroy all of the organic materials that highly found in the sample [25]. Samples with increase in ash contents are expected to have increase in concentrations of various mineral elements, which are expected to speedup metabolic processes and improve growth and development [26]. The sample ash value varied from $14.94 \%$ to $20.54 \%$, were found different between all the Ficus species fruit. F. carica shows the highest ash content compared to others Ficus.

Food energy can also be stated as calories [4]. A calorie can be stated as the quantity of protein, fat and carbohydrate stored in the body [24]. The study conducted by Soni et al. (2014) reported that energy contain in F. carica "Anjir" varieties had highest value of energy (Kcal/100g) and carbohydrate content [12]. It can be supported by the previous study that carbohydrate can be as major components influence the energy value. Based on this study, F. hispida contain high value of energy (175.44 kcal/kJ) compared to other Ficus species fruit. It was proved that the carbohydrate content increase as the energy increases [27]. The samples with high carbohydrate and energy content might be suitable for diabetic and hypertensive patients requiring low sugar diets [28]. The high carbohy- drate and energy content in Ficus fruit species indicate that it contains high in nutritional value and suitable for daily consumption. Currently, $F$. carica becomes more demanding to be consume compared to other Ficus. The consumer prefers more on F. carica due to its fleshy taste of fruit.

\section{Conclusion}

In terms of nutritional content, the highest carbohydrate and energy content was recorded in $F$. hispida. However, for the moisture content, crude lipid, total ash, crude fibre, crude protein $F$. carica recorded the highest value. F. carica cv. BTM6 shows highest in moisture content and leads to increase in crude fibre. F. carica cv. TGF recorded highest in crude protein whilst $F$. carica $\mathrm{cv}$. Alma gives high in crude lipid and total ash value. Based on this study, all the selected Ficus in this study are good in nutritional content. Thus, it had high potential to be commercialized and suitable to be introduces as a food by looking to its benefits on human health.

\section{Acknowledgment}

Special thanks to International Islamic University Malaysia (IIUM) grant (RIGS 15- 128- 0128) for funding my research project. My thanks also go to Kulliyyah of Science, IIUM Kuantan Campus that provides services and facilities during this project conducted.

\section{References}

1. Guo C, Yang J, Wei J et al. (2003) Antioxidant activities of peel, pulp and seed fractions of common fruits as determined by FRAP assay. Nutrition Research 23 (12): 1719 - 1726. doi: 10.1016/j.nutres.2003.08.005. 
2. Hossain ABM, Boyce AN (2009) Fig fruits growth and quality development. Bulgarian Journal of Agriculture Science 15 (3): $189-196$.

3. Ribeiro AB, Bonafé EG, Silva BC (2013) Antioxidant capacity, total phenolic content, fatty acids and correlation by principal component analysis of exotic and native fruits from Brazil. Journal of the Brazilian Chemical Society 2 (24): 797 - 784.

4. Lau E, Goh HJ, Quek R et al. (2016). Rapid estimation of the energy content of composite foods: The application of the Calorie Answer ${ }^{\mathrm{TM}}$. Asia Pacific Journal of Clinical Nutrition 25 (1): $18-25$.

5. Paknahad A, Sharafi M (2015) Benefits of fig as viewed by Islam and modern medicine. International Journal of Agriculture and Crop Sciences 8 (5): $682-685$.

6. Anderson PC, Crocker TE (2013) The Fig. Florida. https://edis.ifas.ufl.edu. Accessed date: April 2019.

7. Flaishman MA, Rodov V, Stover R (2007) The fig: Botany, horticulture and breeding. In Janick J (Ed.), Horticultural. Wiley \& Sons, Chichester. doi: 10.1002/9780470380147.ch2.

8. Berg CC, Corner EJH (2005) Moraceae: Ficeae. Flora Malesiana 17: 1-186

9. Canal J, Torres MD, Romero A, Perez C (2000) A chloroform extract obtained from a decoction of Ficus carica leaves improves the cholestrolaemic status of rats with streptootocin- includede diabetes. Acta Physiologic Hungarica 87 (1): 71 - 76 doi: 10.1556/aphysiol.87.2000.1.8.

10. Rubnov S, Kashman Y. Rabinowitz R et al. (2001) Suppressors of cancer cell proliferation from fig (Ficus carica) resin: Isolation and structure elucidation. Journal of Natural Products 64 (7): 993 - 996. doi: 10.1021/np000592z.

11. Ao c, Li A, Elzaawely AA et al. (2008) Evaluation of antioxidant and antibacterial activities of Ficus microcarpa L. fil. extract. Food Control 19 (10): 940 - 948. doi: 10.1016/j.foodcont.2007.09.007.

12. Soni N, Mehta S, Satpathy G, Gupta RK (2014) Estimation of nutritional, phytochemical, antioxidant and antibacterial activity of dried fig (Ficus carica). Jurnal of Pharmacognosy and Phytochemistry 3 (2): 158 - 165.

13. Slatnar A, Klancar U, Stampar F, Veberic R (2011). Effect of drying of figs (Ficus carica L.) on the contents of sugars, organic acids, and phenolic compounds. Journal of Agricultural and Food Chemistry 59 (21): 11696 - 11702. doi: $10.1021 / \mathrm{jf202707y}$.

14. Veberic R, Jakopic J, Stampar F (2008) Internal fruit quality of figs (Ficus carica L.) in the Northern Mediterranean Region. Italian Journal of Food Science 20 (2): 255 - 262. doi: 10.1016/j.foodchem.2007.05.061.

15. Solomon A, Golubowicz S, Yablowicz Z (2006) Antioxidant activities and anthocyanin content of fresh fruits of common fig
(Ficus carica L.). Journal of Agricultural and Food Chemistry 54 (20): 7717 - 7723. doi: 10.1021/jf060497h.

16. Sadia H, Ahmad M, Sultana S et al. (2014). Nutrient and mineral assessment of edible wild fig and mulberry fruits. Fruits 69 (2): 159 - 166. doi: 10.1051/fruits/2014006.

17. Pugalenthi M, Vadivel V, Gurumoorthi P, Janadhanam K (2004) Comparative nutritional evaluation of little known legumes Tamarandus indica, Erythrina indica, and Sesbania bispinosa. Tropical Subtropical Agroecosystem 4 (3): 107 - 123.

18. Khan A, Khan S, Jan AA, Khan M (2017) Health complication caused by protein deficiency. Journal of Food Science and Nutrition 1 (1): 1 - 2. doi: 10.35841/food-science.1000101.

19. Aerts R, Chapin FS (1999) The mineral nutrition of wild plants revisited: A reevaluation of processes and patterns. Academic Press. Advances in Ecological Research 30: 1 - 67. doi: 10.1016/S0065-2504(08)60016-1.

20. Celestino SMC (2010) Princípios de Secagem de Alimentos; Embrapa Cerrados, Planaltina. Pp 19.

21. Morais DR, Rotta EM, Sargi SC et al. (2017) Proximate composition, mineral contents and fatty acid composition of the different parts and dried peels of tropical fruits cultivated in Brazil. Journal of the Brazilian Chemical Society 28 (2): 308 -318. doi: 10.5935/0103-5053.20160178

22. Hussain J, Rehman N, Al-Harrasi A et al. (2011) Nutritional prospects and mineral compositions of selected vegetables from Dhoda sharif- Kohat. Journal of Medicinal Plants Reserach 5 (29): 6509 - 6514. doi: 10.5897/jmpr11.478.

23. Li YO, Komarek AR (2017) Dietary fibre basics: Health, nutrition, analysis, and applications. Food Quality and Safety 1: 4759. doi: $10.1093 /$ fqsafe/fyx007.

24. US Department of Agriculture, Agricultural Research Service, (USDA Nutrient Database for Standard Reference, Release 15, (2002) Nutrient Data Laboratory retrieved from www.nal.usda.gov/fnic/foodcomp. Accessed on April 28, 2018.

25. Habimana S, Uwamahoro C, Uwizerwa JB (2014) Influence of chicken manure and NPK (17-17-17) fertilizer on growth and yield of carrot. Netherlands Journal of Agricultural Science 2 (4): $117-123$.

26. Bello MO, Falade OS, Adewusi SR, Olawole NO (2008) Studies on the chemical compositions and anti-nutrients of some lesser known Nigerian fruits. African Journal of Biotechnology 7: 3972- 3974.

27. Jung CH, Choi KM (2017) Impact of high-carbohydrate diet on metabolic parameters in patients with type 2 diabetes. Nutrients 9: 322. doi:10.3390/nu9040322.

28. Adaunwo EO, Edori OS, Fubara PE (2013). Proximate and mineral composition of red tree tomato. British Journal of Applied Science \& Technology 3 (4): 1447 - 1454. 